\title{
無蛋白飼料並びにスレオニン欠乏飼料で飼育した \\ シロネズミの筋肉および肝臓蛋白質の異同について

\author{
The Effect of Protein-free and Threonine Deficient Diets on \\ Water Soluble Protein of Muscle and Liver of Rats
}

（昭 和 41 年 3 月 23 日受 理）

$\begin{array}{cccc}\text { 藤 巻 正 生 } & \text { 鈴 木 敦 士 } & \text { 宮 崎 基 嘉* } \\ \text { (Masao Fujimaki) } & \text { (Atsushi Suzuki) } & \text { (Motoyoshi Miyazaki) }\end{array}$

In this report, the properties of water soluble protein extracted from gastrocnemius muscle and liver of rats fed on protein-free and threonine deficien $t$ diets were investigated.

No significant differences in the amino acid composition were detected among the extracts from the rats fed on protein-free, threonine deficient and normal diets. The extracts from gastrocnemius muscle and liver were dialyzed against phosphate buffer at $\mathrm{pH} 5.0$ and fractionated by chromatography on cellulose phosphate by stepwise elution with buffers ranging from $\mathrm{pH} 5.0$ to 10.0 .

From the effluent diagrams of water soluble protein of the muscle, no significant difference was recognized among the rats fed on above-mentioned diets. But the increase of protein fraction coming through with the buffer at $\mathrm{pH} 5.0$ and the decrease of the fraction at $\mathrm{pH} 7.0$ were recognized from the effluent diagrams of water soluble protein of the liver extracted from the rats fed on protein-free and threonine deficient diets.

Tryptophan content and aldolase activity of the fractionated protein were also assayed. No significant difference in the tryptophan content was recognized among the muscle extracts from the rats fed on different diets, but a slight decrease was found in the liver extracts from the rats fed on deficient diets. Aldolase activity of the muscle and liver protein of the rats fed on protein-free diet was slightly lower than that of the rats fed on normal diet, but no difference was observed between the rats fed on threonine deficient and normal diets.

No significant difference in the amino acid composition of the proteins eluted with the phosphate buffer at $\mathrm{pH} 7.0$ was recognized between the rats fed on threonine deficient and normal diets.

\section{緒言}

著者らは，前報1)において，約 2 カ月間無蛋白飼料で 飼ったシロネズミは, 正常に比べると, その筋肉量や, 筋肉中の絾維状並びに球状蛋白質の含量がかなり低く, また短時抽出によるアクトミオシンの粘度や， ATPase 活性などすいくらか差はみられたか，長時抽出によるフ クトミオシンは殆んど差異のなかったことを報告した。

本報では，無蛋白飼料で 5 週間飼ったシロネズミおよ びァミノ酸欠乏の代表としてスレオニン欠乏飼料で 4 週 間飼ったシロネズミについてそれらの筋内および肝臟の 水溶性蛋白質の性質を調べた結果を報告する。

すなわち，筋肉および肝荿の水溶性蛋白質のアミノ酸 組成を分析し，また，セルロースホスフェイトを用いる カラクムロマトダラフィーでそれらを分画し, 各画分に ついて蛋白筫の每比，蛋白筫中のトリブトフェン含量や フルドラーゼ活性を測定した。一方スレオニン久飼
料並びにその対照区である完全アミノ酸飼料て飼有した シロネズミについて, pH 7.0 で溶出される画分の蛋白 質のアミノ酸組成を分析した。

\section{実 験 の 部}

筋肉およひ肝胹抽出液の睭製 : 供試シロネズミは, 表 1 のごとき飼料を用い, 正常区（カゼイン15.2\%区）お よび無蛋白区においてはそれぞれ 5 週間，また正常区 （混合フミノ酸 8.9\%区）およびスレオニン欠乏区にお いてはそれぞれ4週間飼育した。シャネズミの頭部を強 打, 頸動脈を切断, 放血, 屠殺後, 下肢の筋肉並びに 肝臓をとりだし， 1 回の実験に各区 2 匹分を用い供試料 とした。筋肉には，脂肪，結締組織の部分をできるかぎ り取り除いた後, 細切し, その重量の 1.5 倍の冷再溜水 を加え, Waring blendor で2 分間ホモデナイズして, 10,000 rpm で10分間㒉沈した。その上清をセルロース ・チェープ (Visking Company 整) に入れて, pH5.0 
Table 1. Composition of the diets

\begin{tabular}{lcc|lc}
\hline & Normal & Protein free & \multicolumn{2}{c}{ Amino acid diet } \\
\hline Casein* & $15.2 \%$ & $0 \%$ & Amino acid mixture** & $8.9 \%$ \\
Wheat starch & 47.8 & 63.0 & Wheat starch & 54.1 \\
Sucrose & 30.0 & 30.0 & Sucrose & 30.0 \\
Salt mix. & 5.0 & 5.0 & Johnson salt & 5.0 \\
Fiber & 1.0 & 1.0 & Powdered cellulose & 1.0 \\
Soybean oil & 1.0 & 1.0 & Soybean oil & 1.0 \\
Vitamins & enough & enough & Vitamins & enough \\
\hline N level & 2.0 & 0 & N level & 0.98 \\
\hline
\end{tabular}

*Casein, Added with 1\% L-Cystine

**Amino Acid Mixture No. 14 (Miyazaki)

の $0.1 \mathrm{M}$ phosphate buffer で一夜摫拌しながら透析 し, その透析内液を $10,000 \mathrm{rpm} て 10$ 分間遠沈し, その 上清を試料液とした。また肝脿にその重量の 2 倍の冷再 溜水を加え, Waring blendor でホモヂナイズし, 以後上 述の筋肉抽出液の場合と同様に行なって試料液とした。 なお, 筋肉, 肝臓の試料液の一部を倲結して, アミノ酸 分析に供した。

アミノ酸分析 : 凍結試料は, 解倲後, 試料 $0.5 \mathrm{ml}$ に 対し $6 \mathrm{~N}-\mathrm{HCl} 20 \mathrm{ml}$ を加光, 真空下封管し, $110^{\circ} \mathrm{C} て ゙$ 24時間加水分解後，ロータリーエハホポレーターを用い50 ${ }^{\circ} \mathrm{C}$ 以下で $\mathrm{HCl}$ を除いた。ついて $\mathrm{pH} 2.2$ のクェン酸 瑷夜で $20 \mathrm{ml}$ に定容後, その $1.0 \mathrm{ml}$ をベックマン 製アミノ酸アナライザーにかけた。なお，塩基性アミノ 酸用のカラムとしては, $0.9 \times 15 \mathrm{~cm}$, 酸性, 中性アミノ 酸用のカラムとしては， $0.9 \times 50 \mathrm{~cm}$ を用いた。

抽出蛋白票の分画：抽出蛋白質の分画は Fujimaki \& Deatherage の方法"2によって行なった。すなわち，波 長 $280 \mathrm{~m} \mu$ の吸光值にして 100 となるように試料液を とり,これを Cellulose-Phosphate $(1.12 \mathrm{~m} \cdot \mathrm{e} \cdot \mathrm{q} / \mathrm{gBrown}$ 製) を用いるカラム $(2.2 \times 13 \mathrm{~cm})$ に吸着させ緩衝液

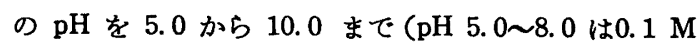

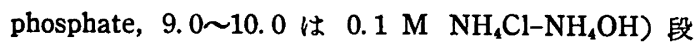
階的にあげ最後に $0.5 \mathrm{M} \mathrm{NaOH}$ で溶出した。溶出液は $5 \mathrm{ml}$ ずつ分取し， $280 \mathrm{~m} \mu$ の吸光值を測定し，また各 画分のピークでは $260 \mathrm{~m} \mu$ の吸光值す測定した。

蛋白所の定目：アミノ酸分析に供した試料およびカラ ムクロマトグラフィーによって分画した後の各画分の蛋 白含量は, Lowry 法帛によって比色定量した。

トリプトファンの定: : カラムクロマトダラフィーに よる分画を行な5前の試料はp-ジメチルアミノベンズア ルデヒド (DABA) を用いる比色法4)で, また分画後の 各画分のピークは, 紫外部吸収法”によって,トリプト ファンを定量し，結果は $\mu \mathrm{g} / 100 \mu \mathrm{g}$-protein で示した。

アルドラーゼ活性の测定：アルドラーゼ活性は, Sib-

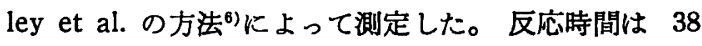
${ }^{\circ} \mathrm{C}$ で0分とした。

なお，試料の調慗およびカラムクロマトダラフィーは $0^{\circ} \sim 4^{\circ} \mathrm{C}$ の低温で行なった。

\section{結果および考察}

5 週間正常飼料（カゼイン15.2\%)，無蛋白飼料で飼 ったシロネズミおよび 4 週間正常飼料（混合フミノ酸 8. 9\%)，スレオニン久乏飼料て飼ったシロネズミの体重 曲線は図 1,2 に示してある。無蛋白飼料, スレオニン欠 乏飼料の両欠乏区とる，前飼育として 1 週間正常飼料を 与えた。なお，飼料はすべて自由投与である。

\section{1. 透析水抽出液の蛋白得含至}

クロマトダラフィーを行なった試料 の波長 $280 \mathrm{~m} \mu$, $260 \mathrm{~m} \mu$ における吸光値並びにその蛋白質含量は表 2 に 示してある。筋肉, 肝荿とすに久乏区でその蛋白質含量 は減少するが，特に無蛋白飼料区の肝荗では，その減少 は大きい。

\section{2. 筋肉・肝藏の水溶性蛋白所のアミノ酸組成}

筋肉および肝荿の透析水抽出液中の蛋白質の構成アミ ノ酸を分析して，その百分率を算出した結果は図 $3 ， 4$ に示してある。Cys, Met は加水分解中に一部破壊され るので（）をつけてある。

筋肉の水溶性蛋白質のアミノ酸組成は, 無蛋白飼料区 およびスレオニン欠乏区の両欠乏区の場合, とすに正常 区に比べて差異がないよ5にみられ，このことは，無蛋 白飼料区において Lys, Ileu, Try, Leu が減少し, 特 に Lys の減少が大きいとしている E. Cardi et al.?)の 報告とは若千異なる。また, カゼイン飼料区と完全ア ミ ノ酸飼料区との両正常区の間, 無蛋白飳料区とスレオ= ン欠乏区の両欠乏区の間にも，そのアミノ酸組成に差界 はみられなかった。肝缄の水溶性蛋白質のアミノ酸組成 は, 無蛋白飼料区，スレオニン久乏区とも，正常区に比 ベて, Asp, Glu がやや多いようにみえるが，全般的に 
Fig. 1. Growth of rats fed on normal and proteinfree diet
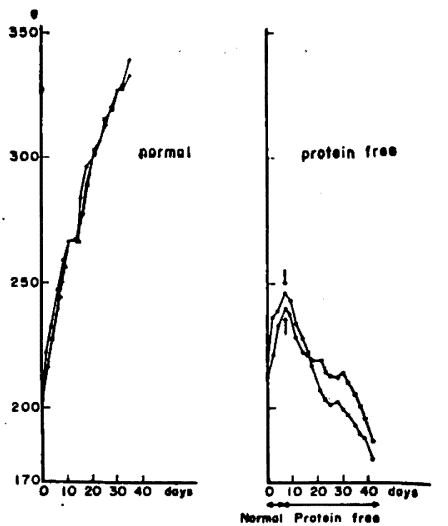

Fig. 3. Amino acid composition of water soluble protein of muscle

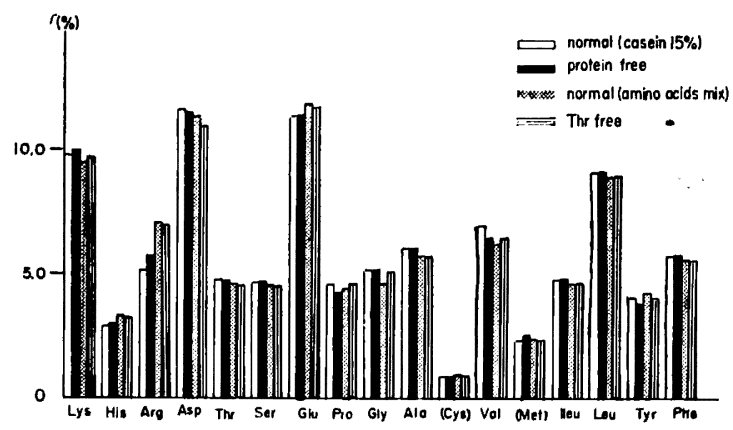

Fig. 2. Growth of rats fed on normal and threonine free diet

Fig. 4. Amino acid composition of water soluble protein of liver
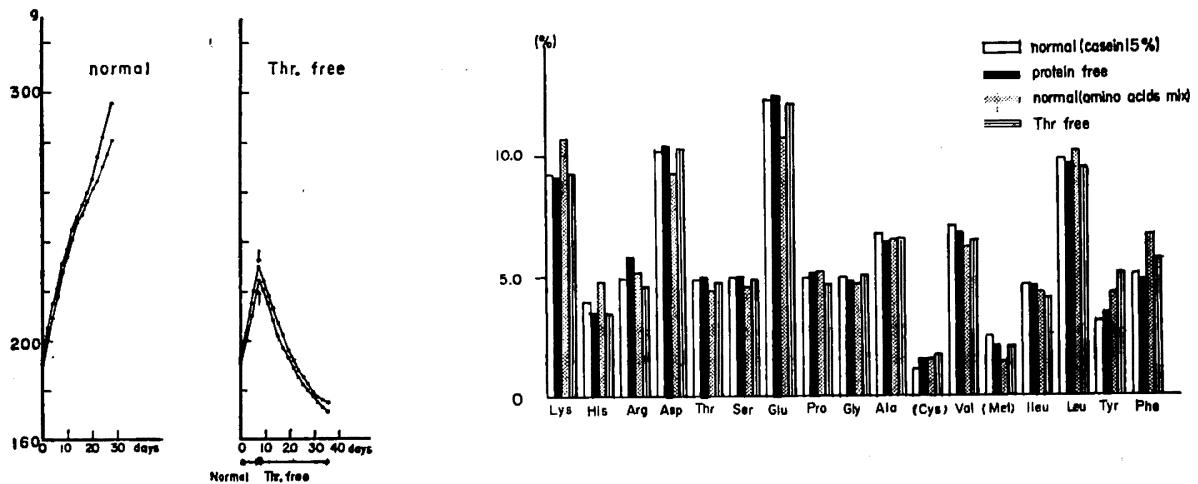

Table 2. Properties of dialyzed water-extractive solution of muscle and liver (Muscle)

\begin{tabular}{l|cc|cc}
\hline & normal & protein free & normal & thr. free \\
\hline O.D. $280 \mathrm{~m} \mu^{*}$ & 0.152 & 0.150 & 0.166 & 0.157 \\
O.D. $260 \mathrm{~m} \mu^{*}$ & 0.102 & 0.100 & 0.120 & 0.106 \\
protein content $(\mathrm{mg} / \mathrm{ml})$ & 15.50 & 13.38 & 18.80 & 17.00 \\
\hline
\end{tabular}

(Liver)

\begin{tabular}{l|cc|cc}
\hline & normal & protein free & normal & thr. free \\
\hline O.D. $280 \mathrm{~m} \mu^{*}$ & 0.283 & 0.205 & 0.284 & 0.254 \\
O.D. $260 \mathrm{~m} \mu^{*}$ & 0.205 & 0.175 & 0.210 & 0.207 \\
protein content $(\mathrm{mg} / \mathrm{ml})$ & 17.88 & 9.50 & 22.50 & 17.00 \\
\hline
\end{tabular}

* (1: 100 dilution $)$ 
Fig. 5. Chromatogram of water soluble protein of skeletal muscles from rat fed on normal and protein free diet on cellulose phosphate
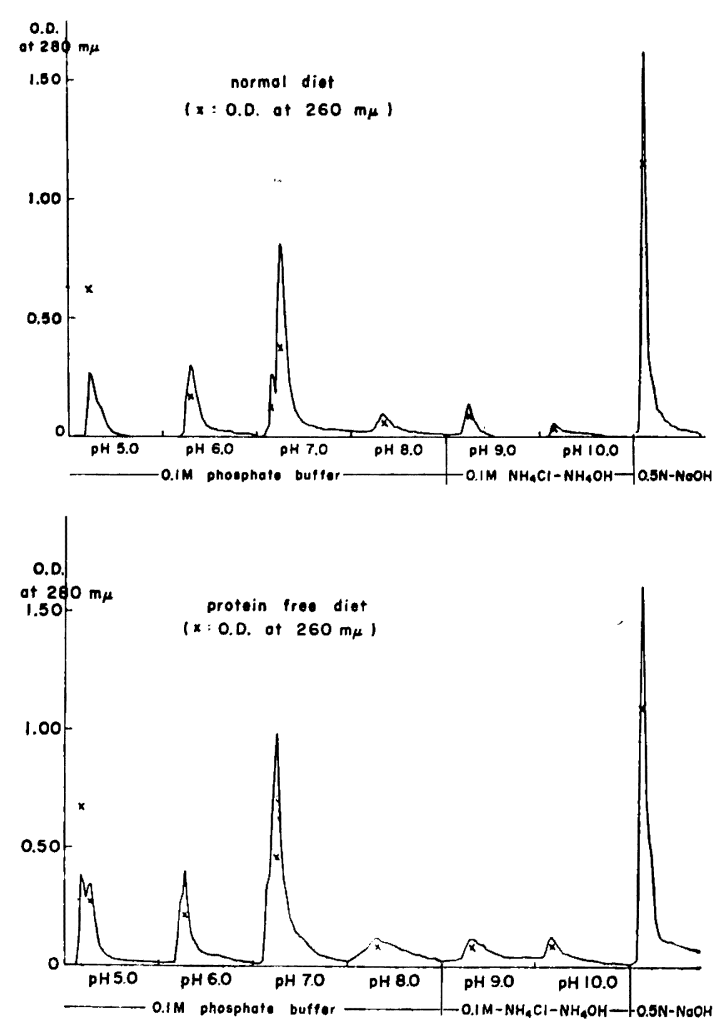

差はないと考えられる。カゼイン飼料区と完全アミノ酸 飼料区の両正常区の間, 無蛋白飼料区とスレオニン欠乏 区の両欠乏区の間では，筋肉の場合と同様に差異はみら れなかった。

3. 水溶性蛋白質のカラムクロマトクララィー

得られたクロマトダラムは四5,6,7,8,に示してある。 筋肉については, 正常区, 無蛋白区およびスレオニン欠 そ区の間に全く差異はみられなかった。肝䁍では, 無蛋 白区,スレオニン欠乏区共に，正常区に比べて $\mathrm{pH} 5.00$ 緩衝液で吸着されない画分の蛋白質が增し， $\mathrm{pH} 7.0$ で 溶出される画分の蛋白質が隇少する傾向がみられた。筋 肉, 肝荗とすに, カゼイン飼料区と完全アミノ酸飼料区 の両正常区の間, 無蛋白飼料区とスレオニン欠乏区の両 欠乏区の間に明確な差はみられなかった。

\section{4. トリプトファン合量}

表 3 に示してあるよ5に, 筋肉では, 無蛋白飼料区, スレオニン欠乏区とすに正常区との差はみられなかった が肝臟では，両欠乏区の場合，正常区上りやや減少する 傾向がみられた。

\section{5. アルドラーゼ活性}

Fig. 6. Chromatogram of water soluble protein of muscles from rat fed on normal and threonine free diet
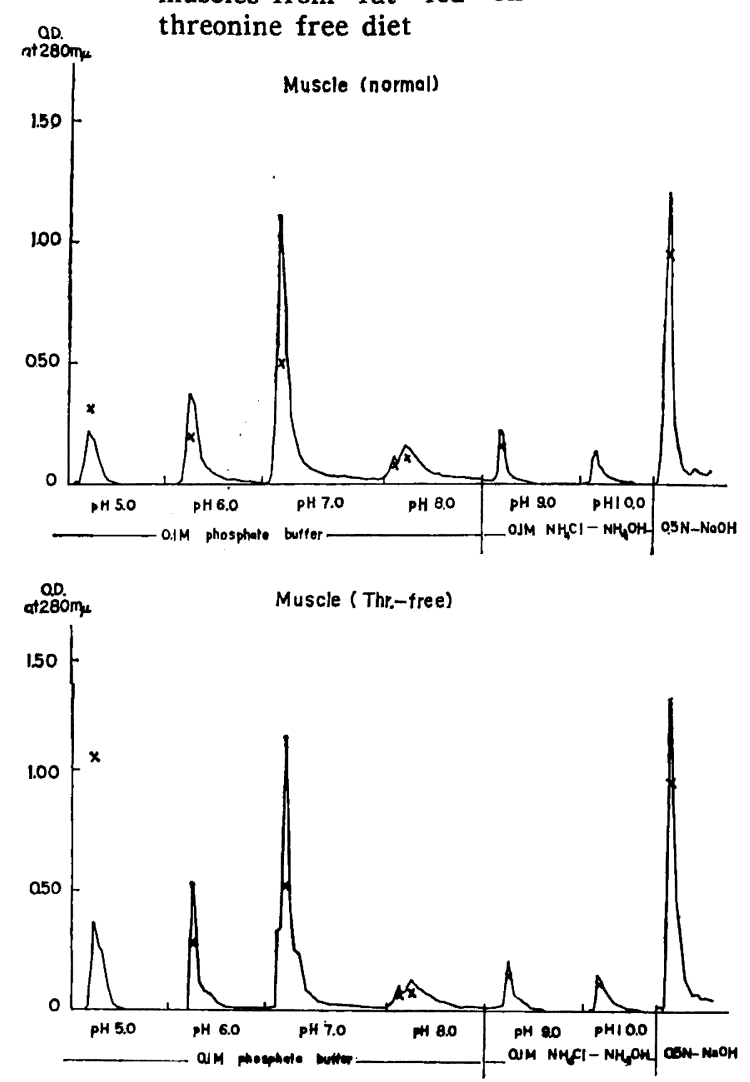

Cellulose-Phosphate を用いるクロマトグラフィーに より筋肉, 肝蔵の水溶性蛋白質を分画した結果, アルド ラーゼ活性は, $\mathrm{pH} 7.0$ の緩衝夜で溶出される画分にの み認められた。表 4 に示してあるよ 5 に, 筋肉, 肝蔵と すに無蛋白飼料区の場合, 正常区に比べてやや減少した が、スレオニン欠乏区では差は生じなかった。

6. pH 7.0 の暧街液で溶出される蛋白翼のアミノ酸 組成

スレオニン欠乏飼料および完全アミノ酸飼料で飼った シロネズミの筋肉, および肝荿からの抽出液をカラムク ロマトグラフィーにかけた場合, $\mathrm{pH} 7.0$ の緩衝液で溶 出される蛋白質画分のアミノ酸組成を分析し, 構成アミ ノ酸の百分率を算出した結果は, 図 9,10 に示してある ように，筋肉の場合，スレオニン欠乏区と正常区との間 に全くその差はみられなかった。また肝橫の場合も，ス レオニン欠乏区と正常区との間に，觔肉の場合と同様に 全く差がみられなかった。カラムクロマトグラムから, スレオニン欠乏の場合にこの画分は減少する傾向がみら れたが，その構成フミノ酸組成には差がなかった。すな わち，欠乏区の場合この画分に溶出されてくる蛋白質旦 
Fig. 7. Chromatogram of water soluble protein of liver from rat fed on normal and protein free diet on cellulose phosphate
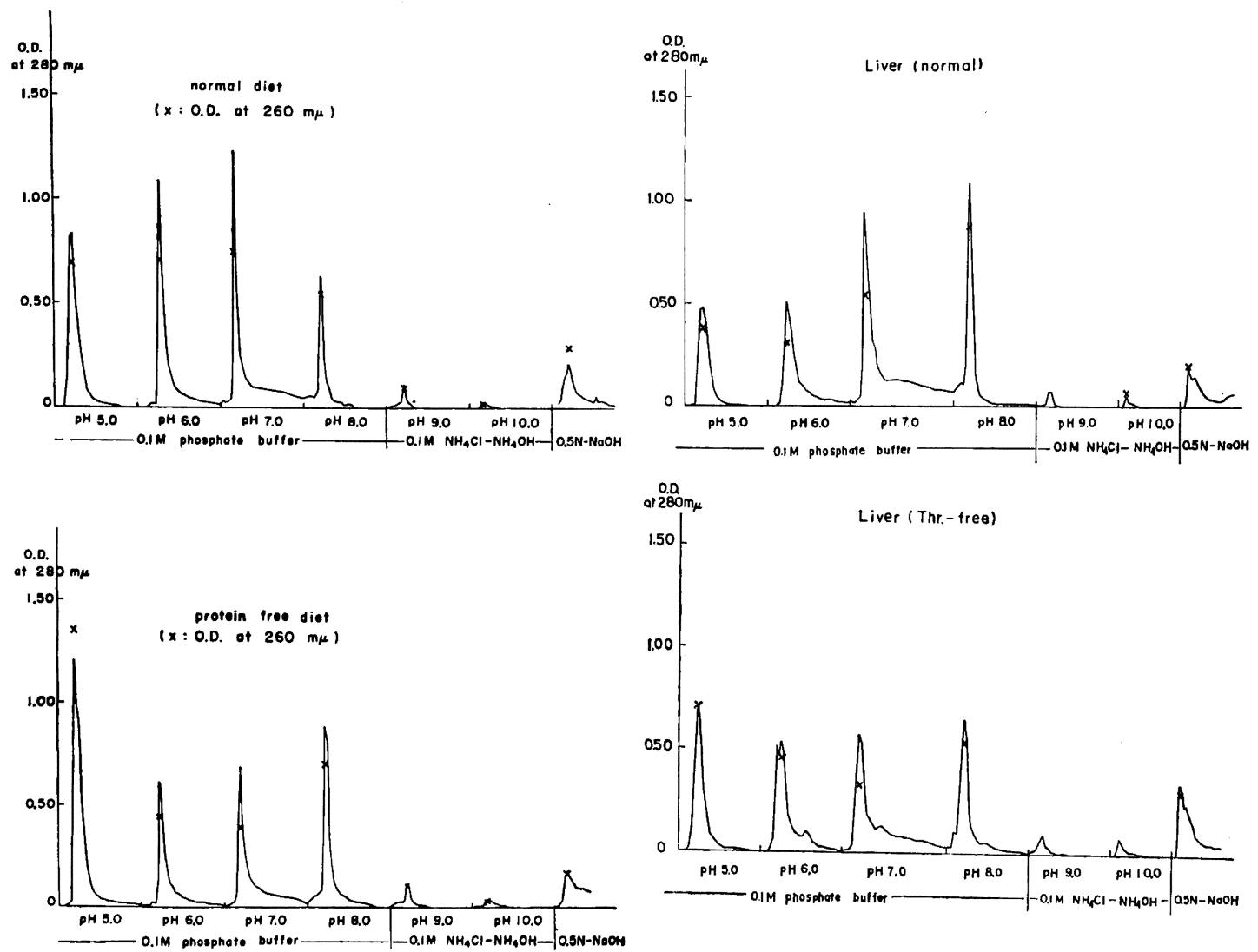

Table 3. Tryptophan contents ( $\mu \mathrm{g} / 100 \mu \mathrm{g}$ protein)

(Muscle)

\begin{tabular}{c|cc|cc}
\hline & normal & thr. free & normal & protein free \\
\hline dialyzed water-extract & 1.77 & 1.76 & 2.13 & 2.02 \\
fraction at pH 6.0 & 2.32 & 2.33 & \\
at pH 7.0 & 1.61 & 1.60 & \\
at pH 8.0 & 1.81 & 1.76 & \\
at pH 9.0 & 1.15 & 1.19 & \\
\hline
\end{tabular}

(Liver)

\begin{tabular}{c|cc|cc}
\hline & normal & thr. free & normal & protein free \\
\hline dialyzed water-extract & 1.94 & 1.84 & 2.64 & 2.10 \\
fraction at $\mathrm{pH} \mathrm{6.0}$ & 2.04 & 1.88 & \\
at $\mathrm{pH} \mathrm{7.0}$ & 2.28 & 2.20 & \\
at $\mathrm{pH} \mathrm{9.0}$ & 1.58 & 1.23 & & \\
\hline
\end{tabular}

Table 4. Aldolase activity (fraction at $\mathrm{pH} 7.0$ ) $\Delta \mathrm{E}$ at $540 \mathrm{~m} \mu / \mathrm{mg}$ protein

\begin{tabular}{l|rr|rr}
\hline & normal & thr. free & normal & protein free \\
\hline Muscle & 517 & 501 & 708 & 450 \\
Liver & 116 & 133 & 96 & 67 \\
\hline
\end{tabular}


Fig. 9. Amino acid composition of the fraction eluted with $\mathrm{pH} 7.0$ buffer (Muscle)

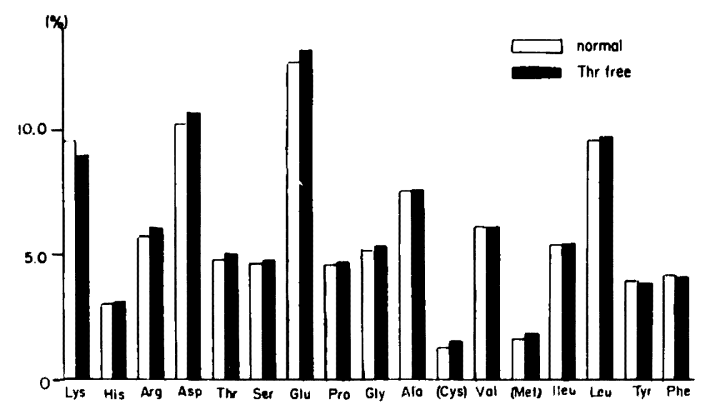

Fig. 10."Amino acid composition of the fraction eluted with $\mathrm{pH} 7.0$ buffer (Liver)

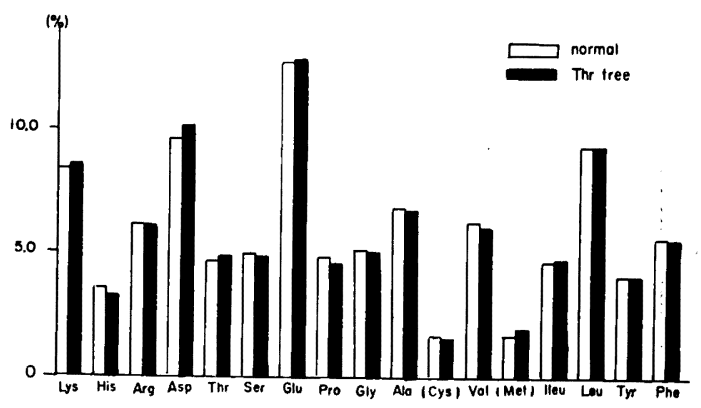

は減少するがそのアミ/酸組成は変わってないことがわ かった。

要䄪

無蛋白飼料で 5 週間飼ったシロネズミとスレオニン欠 乏飼料で 4 週間飼ったシロネズミの筋肉並びに肝臓の水 溶性蛋白質のアミノ酸組成は，それぞれの正常区に比べ て明らかな差は認められず，またカゼイン飼料区と完全 アミノ酸飼料区の両正常区間，あるいは無蛋白飼料区と スレオニン欠乏飼料区の両欠乏区の間にも差は認められ なかった。

セルロースホスフェイトを用いるカラムクロマトグラ フィーにより水溶性蛋白質を分画した結果, 筋肉の場
合，各画分り量比，蛋白質中のトリブトファン含量には 正常区，無㔻白区，スレオニン久乏区の間で差はみられ なかった。しかし, 肝䑏については, 無蛋白区, スレオ ンン欠乏区ともに正常区に比べて $\mathrm{pH} 5.0$ の䌅衝液で吸 着されない蛋白質が增加し， pH 7.0 で溶出される画分 の蛋白質は減少し, 各画分の蛋白質中のトリプトファン 含量も正常区に比べてやや減少する傾向がみられた。

フルドラーゼ活性は, 筋肉, 肝脿ともに無蛋白区の場 合は, 正常区に比へててやや減少したが，スレオニン欠乏 区の場合には，その差はみられなかった。

スレオニン欠乏飼料扰よび完全アミノ酸飼料で飼った シロネズミの場合, カラムクロマトグラフィーで分画後 $\mathrm{pH} 7.0$ 緩衝夜で溶出される蛋白質画分のアミノ酸組 成を分析した結果, 筋肉, 肝臟ともにスレオニン久乏区 と正常区の間に全く差はみられなかった。

終わりに，本研究に終始ご懇篤なご指導を賜わった東 京大学教授桜井芳人先生に厚くお礼申し上げます。

アミノ酸分析は, 食糧研究所の田村真八郎氏, 東京大 学農学部農芸化学科栄養化学教室に依頼した。記して謝 意を表する。

（本研究の一部は, 第30回必須フミノ酸研究委員会およ び第19回日本栄養·食糧学会総会で発表した。)

\section{文献}

1) 藤巻正生, 原田真知子 : 栄養と食糧, 19,156(1966)

2) Masao Fujimaki \& F. E. Deatherage: J. Food Sci., 29, 316 (1964)

3) Lowry, O. H. et al.: J. Biol. Chem., 193, 265 (1951)

4) Spies, J. R. \& Chambers, D. C.: Anal. Chem., 20, 30 (1948)

5) Goodwin, J. W. et al.: Biochem. J., 40,628 (1946)

6) Sibley, J. A. et al.: J. Biol. Chem., 177, 859 (1949)

7) E. Cardi et al.: Quaderni Nutr., 20, 162 (1960)

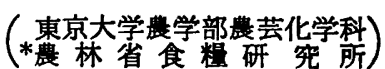

